\title{
O ÊXODO NA TRAGÉDIA HIPÓLITO DE EURÍPIDES
}

\author{
Fernando Crespim Zorrer da Silva*
}

RESUMO: The exodus constitutes a meaningful structural part in the tragedy Hippolytus by Euripides. In this tragedy, the exodus reveals Theseus as a proud, arrogant man with a limited understanding of the world; a man whose lack of consideration and self-examination contribute in the destruction of his family. Also in the end of the tragedy, the goddess Artemis criticizes Phaedra, Theseus' wife, and also Hippolytus, though indirectly, despite her close and affectionate relationship to him. In fact, this young man will be worshiped in Troezen by women who will make him a special praise before they get married. In this sense, Hippolytus is ironically criticized, for he has shown throughout this tragedy that he could not tolerate women, and that he even hated them; besides, it is precisely the son of Theseus that will be associated to marriage, an institution characterized by motherhood, affection exchange, and sex, elements that were criticized and repudiated by him.

PALAVRAS-CHAVE: Eurípides, Tragédia Grega, Hipólito, Fedra, Teseu, Êxodo.

Tratar do êxodo de uma tragédia consiste em analisá-lo bem como recuperar a leitura de toda a obra. Tal procedimento não é unicamente um recurso literário mas também reflete o próprio pensamento do tragediógrafo. A coerência de seu texto é, de fato, evidenciada principalmente no final da sua obra, pois ali se observa se realmente tudo está bem concatenado, como os personagens, a trama, o enredo, a divisão dos episódios, a fala do coro, o párodo, enfim, há uma série de itens que são recuperados no êxodo de uma forma ou de outra. É interessante observar que no texto A poética (1452 b) de Aristóteles, esse pensador refletiu pouco sobre o êxodo ( $\xi_{\xi} \mathrm{o} \delta \mathrm{o} \varsigma$ ), destacando ser uma parte completa a qual não é seguida por uma fala do coro.

No caso das tragédias de Eurípides, esse quadro sugerido acima, no qual se destaca a importância do desfecho de uma tragédia, não é diferente. A fim de detalhar a construção dramática do êxodo em uma tragédia da obra de Eurípides, é oportuna a interpretação da peça Hipólito, apresentada em 428, cujo desfecho da narrativa reúne uma divindade, Ártemis, filha de Leto e de Zeus; Teseu, rei de Trezena e esposo de Fedra, que já está morta, porém é ainda mencionada; Hipólito, filho de Teseu que, naquele momento, chega à cena à beira da morte. Vale lembrar que Teseu contribuiu decisivamente no futuro terrível de seu filho.

O êxodo ocorre justamente com a entrada de Ártemis; por sua vez, tal fato remete ao prólogo pronunciado por Afrodite, isto é, o início e o fim da tragédia possuem as falas de duas divindades — as duas são filhas de Zeus. Se, anteriormente, Cípris (Afrodite) revelou o seu poder, que, dentre outras informações e atos, destaca-se a

* Doutor em Letras Clássicas pela USP e é pesquisador na área de Literatura Grega e Comparada. 
anunciada destruição de Hipólito (é importante ressaltar que ele é filho de uma amazona, conhecida como Hipólita), agora, é a vez de Ártemis, que, pouco fala de si mesma, porém, em resumo, procura defender o filho de Teseu. Na verdade, destaca-se que essa deusa chama a atenção de Teseu através de um verbo semelhante (em termos

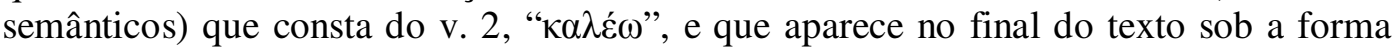

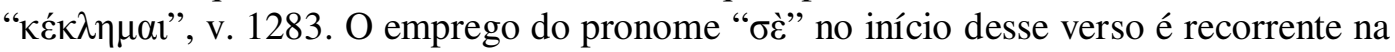

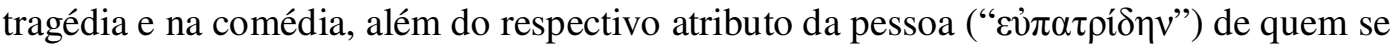
está evocando (Barrett, 1964, p. 396-397). Observa-se, aliás, que este verbo é empregado pelo tragediógrafo para chamar a atenção de Teseu por ter cometido um

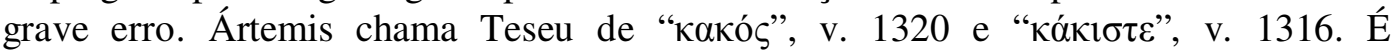

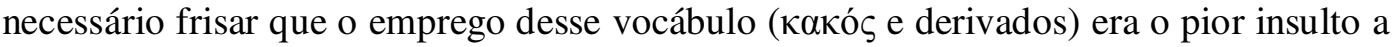
ser dado a um herói (Férez, 1988, p. 61); por exemplo, Jasão é assim qualificado com essa denominação na tragédia Medéia, por sua esposa, conforme os versos 229 e 465.

É digno de nota destacar que a fala da divindade fornecerá uma nova visão sobre a paixão amorosa de Fedra pelo enteado. Em nenhum momento, Ártemis menciona que Hipólito tenha ofendido Afrodite - a primeira deusa silencia sobre esse assunto. Ártemis explica a reação de Cípris, por atacar aqueles que possuem prazer com a virgindade, conforme os versos 1301 ss. Trata-se, assim, de um outro aspecto do divino. Será que Afrodite é tão tola e fútil que matou dois mortais somente porque Hipólito desfrutava do prazer da virgindade e não do sexo e da paixão? Será que Afrodite mentiu a respeito de Hipólito, e a defesa de Ártemis está correta? Neste sentido, a tragédia de Eurípides apresenta desde o prólogo até o êxodo tais questionamentos e não respostas diretas, como, por exemplo, aja assim e será feliz, faça isto e terá êxito na vida.

Como Ártemis possui prazer pela virgindade, a deusa critica os atos de Fedra ao afirmar que, v. 1300-1303,

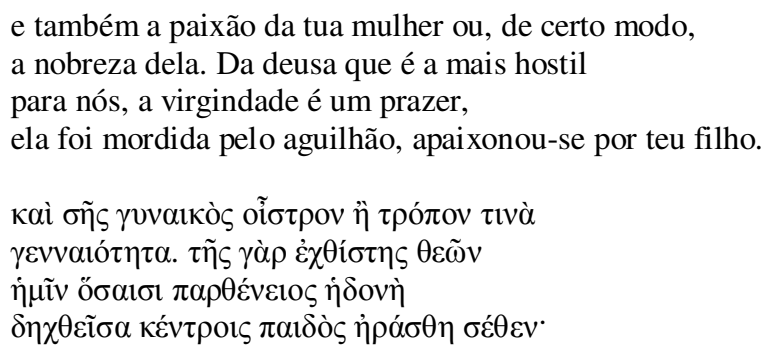

A deusa citada acima não aceita plenamente a nobreza da rainha quando profere a

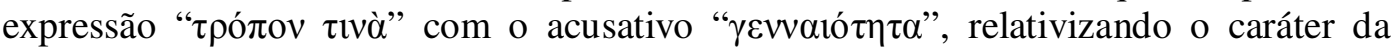
heroína. A paixão é, de certa forma, condenada pela deusa e não possui importância na vida dos mortais - tal divindade nem comenta este assunto. A seguir, Ártemis apresenta uma narrativa que dialoga com a fala de Afrodite (proferida no prólogo), acentuando aspectos que passaram despercebidos por Teseu. Esse relato dos fatos resume o mecanismo empregado por Fedra para barrar a paixão, conforme o v. 1304,

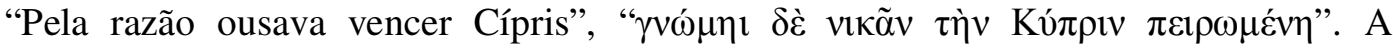
reflexão da deusa remete à longa fala de Fedra, que ocorre no primeiro episódio na qual revelou os diversos meios empregados para repelir a paixão. Lester Crocker destaca que Fedra padece de forças perigosas que fazem parte da sua natureza; ao mesmo tempo, luta contra isso, empregando a razão, a disciplina e a ordem (Crocker, 1957, p. 243 ss).

Com efeito, a divindade reconhece as adversidades que a rainha experimentou, ao tentar impedir os avanços da paixão. Ártemis sabe o que ocorreu entre Hipólito e 
Fedra e a deusa não pôde agir sobre isso. Neste momento, a aia torna-se importante na tragédia e, pela primeira vez — na ótica de outro personagem, isto é, de Ártemis —, deixa de ser apenas uma serva, de acordo com o v. 40, que foi proclamado por Afrodite, pois, segundo a primeira deusa, Fedra foi "destruída sem querer pelas maquinações da

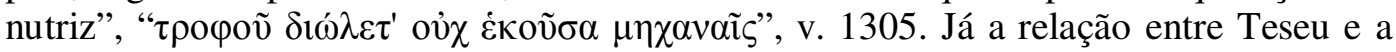
aia é a seguinte: o rei é criticado por inúmeros motivos, dentre os quais não chamou a nutriz para questioná-la e para utilizá-la como uma segunda opinião sobre a morte de Fedra. De fato, essa 'segunda mãe' era uma figura significativa no palácio e Teseu desprezou o papel dessa mulher.

Vale ressaltar agora que Ártemis está com Hipólito. Não há como negar a proximidade da relação entre esses dois seres. Isso já aparece no prólogo: Afrodite e Hipólito referem-se a tal relacionamento. No terceiro episódio, o filho de Teseu anunciou que ele e a deusa partiriam de Trezena - ambos estão, com certeza, juntos quando proclama tal afirmação. O que se pode esperar mais dessa parceria? A combinação das palavras entre homem e deusa é reveladora do estreitamento desse tipo de contato afetivo.

Fedra e Teseu acusaram Hipólito de que este último tivesse violentado sexualmente a rainha. Em contrapartida, Ártemis e o filho da amazona defenderam-se da acusação. O esposo confiou na mulher, ao passo que Ártemis não aceitou essa perspectiva. A divindade adverte o rei de Trezena de que este último não utilizou o poder dos adivinhos, nem verificou se havia outras provas de acusação contra o filho, julgando-o rapidamente, de forma parcial - trata-se, aqui, pois, de dois momentos. $\mathrm{O}$ primeiro envolve a decisão de Teseu antes do diálogo com o seu filho. A outra situação abarca as reclamações de Hipólito contra o seu pai, questionando os seus métodos de julgamento. Mais uma vez, Ártemis demonstra que estava próxima de tudo aquilo que sucedia no mundo dos mortais. É curioso registrar que os versos 1321-1324 (proclamados pela filha de Leto) correspondem aos versos 1051-1052 e 1055-1056 (nestes, Hipólito questiona o julgamento de seu pai). Trata-se, deste modo, de um mecanismo para confirmar que o filho da amazona estava certo ao inquirir o seu pai a respeito de suas decisões.

Na tragédia, não há um motivo esclarecedor a respeito da ausência de Teseu do palácio. No entanto, Ártemis confessa o motivo por estar 'ausente' dos acontecimentos que suscitaram as mortes de Fedra e de Hipólito. O dramaturgo, assim, justifica a defesa da deusa diante dos mortais, explicação esta que não é fornecida por Teseu. Zeus é o limite para a sua filha não poder ajudar o fiel servidor desta última(o filho da amazona), v. 1397. Teseu não possui argumentos a seu favor, que justifiquem a sua ausência do palácio. Há, neste sentido, um paralelismo entre as ausências de um e de outro, isto é, entre Teseu e Ártemis. A censura desta ao primeiro (que acreditou na rainha e na sua reação contra a paixão) é que os mortais teriam outros meios para se salvar de determinados conflitos. O discurso da deusa é cruel contra Teseu e aproxima-se, até mesmo, do escárnio, quando indaga, v. 1290-1293,

Como não te escondes debaixo da terra no Tártaro,

envergonhado pelo teu corpo,

ou mudas a vida às alturas, como um pássaro,

para que suportes a tua calamidade?

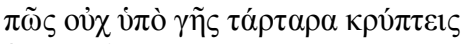

$\delta \varepsilon ́ \mu \alpha \varsigma \alpha i \sigma \chi v v \theta \varepsilon i ́ \varsigma$,

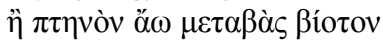

Organon, Porto Alegre, nº 49, julho-dezembro, 2010, p.239 - 256 
Anteriormente Teseu revelou, de forma enfática, logo que soube da morte da esposa, que gostaria de lançar-se para debaixo da terra no momento em que morresse, v. 836837. É importante lembrar que o texto dramático não registra que esse personagem tenha lançado sequer uma lágrima pelo falecimento da sua mulher. A morte, nesse ponto do êxodo, é a recompensa que o marido recebe ao confiar na sua esposa. Ele errou ao ser enganado por Fedra, justamente por aquilo que é ensinado às mulheres: permanecer em silêncio em casa. A rainha deixou uma carta, antes de cometer o suicídio, na qual acusa Hipólito de que a tenha ultrajado sexualmente. É revelador que a escrita poderia 'gritar' alguma coisa; mesmo assim, tal texto está envolvido com o silêncio. $O$ cadáver de Fedra igualmente carrega essa marca - nem a carta, nem o corpo podem ser 'questionados'. O significado do corpo e do texto pode ser compreendido em uma única linha interpretativa, como o próprio Teseu assim o fez, além de ter unido esses dois elementos como provas irrefutáveis contra o seu filho. $\mathrm{Na}$ verdade, através do silêncio, ocorre a acusação contra Hipólito e este não teve capacidade (não soube escolher as palavras, foi arrogante, julgando-se acima de todos os mortais) para se defender diante das acusações de seu pai.

É importante registrar que não se sabe com certeza se Teseu retornou do Hades. Claro está que, após saber da morte de Fedra, o rei desejou a morte para si mesmo. No início do êxodo, com a presença de Ártemis, a deusa indaga Teseu porque este último não se encaminha para aquele lugar ou para algo similar como uma gruta. A conclusão é que Teseu parece não ter aprendido nada nessa sua viagem, pois é enganado por Fedra que consegue enviar Hipólito para o mundo dos mortos. Por sua vez, o coro (constituído por mulheres), que sabia a verdade — no entanto, estava proibido de falar — , tentou demover Teseu da maldição que ele lançou contra o seu próprio filho.

No discurso de Ártemis, encontra-se a imagem do pássaro que foi comentada por Teseu ao se referir à morte de Fedra, quando aquele personagem proclama, v. 828-829, "Como uma ave das minhas mãos desapareceste, / com um salto veloz te arremessaste

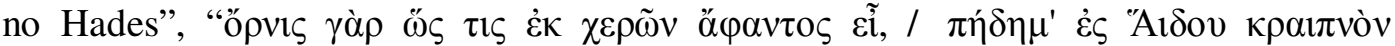

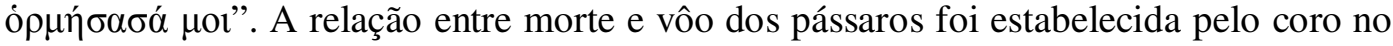
segundo estásimo e é retomada com toda a força, além de ser alvo de sarcasmo contra Teseu. Robert Eisner assevera que, quando Ártemis, ao pedir a Teseu que se transforme em um pássaro ou que vá para os Infernos, isso se constitui em um indicativo de que Teseu descerá até o Hades com Perítoo, será exilado em Scyros, morrendo na obscuridade e no isolamento (Eisner, 1979, p. 161). Na concepção de Charles Segal, Teseu realizará o primeiro dos pedidos a Posídon, e esse aspecto justifica a dúvida quanto à paternidade e à dupla condenação de Hipólito. Como se sabe, Teseu solicitou a esse deus que matasse Hipólito e que, se não fosse possível, mandasse-o embora em exílio. (Segal, 1972, p. 173).

Além disso, Ártemis alivia a culpa do pai por ter tramado o assassinato do filho,

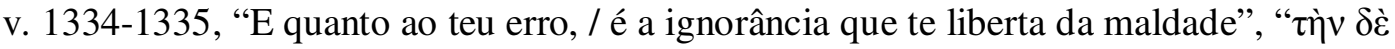

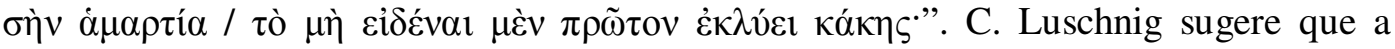
ignorância é um sentimento freqüente que ocorre na peça de Eurípides (Luschnig, 1983, p. $115 \mathrm{ss})$. Também salienta que é difícil encontrar outra tragédia na qual existam tantas personagens a exibirem diferentes níveis de ignorância. Essa falta de conhecimento que a helenista menciona não se situa unicamente no plano do conhecimento, das verdades, porém amplia-se no horizonte das relações de afeto, nas quais um personagem 
demonstra ter um conhecimento precário sobre os seus sentimentos e sobre os dos outros indivíduos com os quais mantêm algum tipo de envolvimento. Neste sentido, a ignorância é inseparável da condição humana, conforme o discurso de Ártemis, v. 14331434; além disso, é algo que dificulta o desenvolvimento da paixão e que permite a morte da madrasta e do enteado. O coro e Hipólito simulam a ignorância (o desconhecimento do que, realmente, sucedeu com a rainha) diante de Teseu, para cumprirem os juramentos no plano da linguagem dos homens. Desta maneira, silêncio, juramento e ignorância aliam-se, perfazendo a eliminação da paixão de Fedra. Nessa nova realidade que foi gerada, Hipólito estaria completamente deslocado. Ele realmente colaborou na sua própria morte e na de Fedra, pois permitiu que a ignorância se transformasse em um dos pontos decisivos para as ações de Teseu.

Ártemis, em seu discurso, ressalta o poder da palavra. Como exemplo disso, observam-se duas passagens nas quais os vocábulos são decisivos para que, na prática, a rainha tivesse o poder de persuasão. No entendimento daquela divindade, Teseu "foi

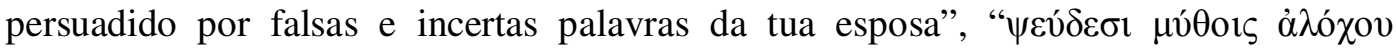
$\pi \varepsilon 1 \sigma \theta \varepsilon i \varsigma / \alpha \grave{\alpha} \varphi \alpha v \tilde{\eta}$ ", v. 1288-1289, e a rainha "escreveu acusações enganosas e destruiu, /

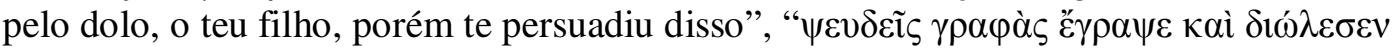

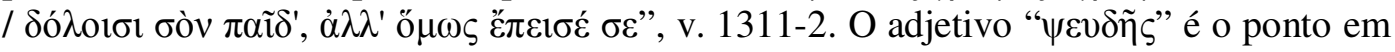
comum nessas duas passagens e foi retomado duas vezes. Essa incidência revela que o discurso de Fedra (a carta) - para se proteger contra a acusação — forja a verdade e encaminha a morte de Hipólito; também, permite que o sentimento da paixão fique a salvo das especulações de Teseu e que a rainha possa, assim, morrer com a honra intacta. Por fim, a paixão deverá entrar na esfera do esquecimento e que, quando é revelada, provocará a destruição.

Há uma tendência, na crítica especializada, a considerar Ártemis e Afrodite, em Hipólito, como poderes que se opõem. Charles Segal demonstra que essa abordagem simplifica o universo de atuação das divindades (Segal, 1965, p. 117 ss). Esse helenista julga que as deusas representam poderes cósmicos, porém elas são maiores que aquilo que elas significam, v. 359-361, isto é, equivalem a extensões ou a projeções de todas as nossas paixões que se movimentam dentro da alma - além, é claro, da relação que elas mantêm com os impulsos do mundo natural, v. 443-450 (Id., 1972. p. 177). Na verdade, não se reproduz, aqui, a estrutura que poderia ser observada em Alceste. Nesta tragédia, na concepção de André Rivier, Morte e Apolo estabelecem contrastes entre a luz e a escuridão, entre a vida e a morte, entre o dia e a noite - a complexidade entre Ártemis e Afrodite não se encontra, pois, na díade Morte-Apolo (Rivier, 1975, p. 32 ss). Certamente, Eurípides revela que a paixão não pode ser compreendida como algo que não possua qualquer tipo de relação com Ártemis e como algo que tenha plena relação com Cípris; mais do que nunca, a paixão compreende diversos níveis que abrangem o sagrado e o profano.

O êxodo também descreve a dor e o mal-estar de Hipólito, enfatizando os últimos momentos de vida desse personagem — seu corpo tornou-se digno de comiseração, porque se apresenta em um estado lastimável. Destaca-se, aqui, o contraponto com o estado físico de Fedra antes do suicídio: a cabeça, as mãos e os cabelos são mencionados por esta última que roga auxílio às servas a fim de que a sustentem; o seu corpo está fraco, aliás, faz três dias que não mais ingere algum alimento, v. 135 ss. Agora, o corpo de Hipólito igualmente sofre pela paixão, não da mesma forma como o ardor que Fedra sentiu pelo jovem, mas sim por não tê-la aceitado ou, pelo menos, por ter carecido de bom senso ao se deparar com uma declaração 
amorosa (a aia havia tentado aproximar a madrasta e o enteado; contudo, este último repudiou isso de forma violenta e ameaçadora). Assim, Hipólito experimenta o outro lado da paixão: a destruição - é o mesmo caminho de Fedra. Deste modo, a morte, para os personagens, resultou no término dos males provocados pela paixão.

Além das reclamações contra o pai, Hipólito ainda não compreende o que está acontecendo na sua vida; também, não admite que existam seres que fogem ao nosso poder, como os animais, conforme os versos 1355-1357: "Ó odiosos cavalos do carro,

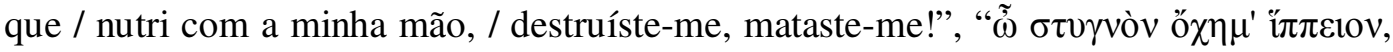

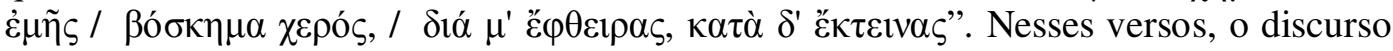
do jovem relaciona-se com o pretenso poder proferido no prólogo, quando o personagem ostentou força e domínio sobre a situação. É interessante citar aqui o prólogo da peça Fedra, de Sêneca, pois neste a fala de Hipólito ostenta grande poder e força, além de ser o único personagem a ter a chance de se manifestar primeiramente nesse drama. Também sobre essa tragédia, não há um personagem como um servo, como sucede na peça de Eurípides, que questione Hipólito a respeito de sua repulsa a Afrodite.

Retomando Eurípides, com o corpo em estado lastimável, Hipólito não se conforma com aquilo que está ocorrendo em sua vida, v. 1364-1369:

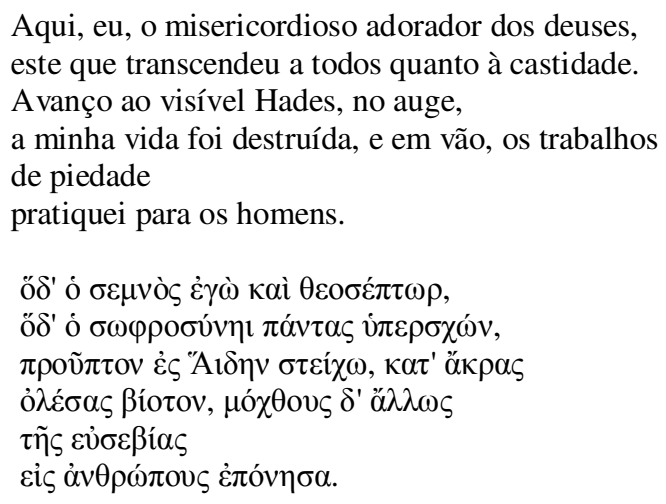

O personagem estaria a pensar em Ártemis e Zeus; contudo, quanto a Afrodite, será que

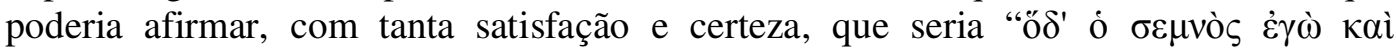
$\theta \varepsilon 0 \sigma \varepsilon ́ \pi \tau \omega \rho "$ ? A fala de Hipólito revela o quanto este mantém os seus propósitos e as suas convicções, pois nada parece afetá-lo. O filho de Teseu não compreende que habita um mundo cheio de regras e de mistérios, onde não acontece tudo o que se quer. Neste sentido, Hipólito, afastou-se dos mortais, uma vez que criou outro espaço para si mesmo e para a sua divindade predileta (Ártemis), a saber, o prado (conforme o prólogo). Esqueceu que ainda pertence a um lugar que ele quer evitar e que se distanciou: o palácio de Fedra e de Teseu.

A dor das lacerações do seu corpo possibilitou que o personagem - cuja soberba e segurança em seu comportamento julgavam proteger-lhe — aprendesse o que é ter o corpo destruído por algo que não se reconhece, por qual razão sucedeu a sua exposição ao sofrimento. Fedra também experimentou isso, quando, no seu longo discurso, v. 373-430, refletiu sobre os motivos que levavam as pessoas a realizarem atos que podem ser condenados.

A posição de Hipólito, diante dos últimos acontecimentos, é acreditar que um elemento exterior esteja atuando em sua desgraça. O filho da amazona não considera que ele próprio possa ter algum tipo de responsabilidade sobre aquilo que ocorre em sua 
vida - por isso, o personagem outorga o infortúnio às funestas imprecações de Teseu, v. 1347-1349, "Ai, ai! / Eu sou infeliz, por causa de um pai injusto, / fui lacerado por

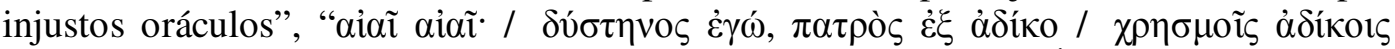
$\delta 1 \varepsilon \lambda \nu \mu \alpha ́ v \theta \eta \nu$ ". Tal idéia é retomada quando Hipólito proclama: "Ó imprecação funesta

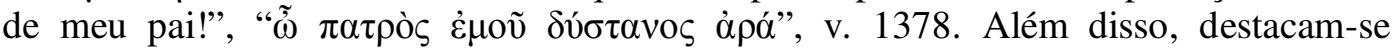
igualmente os versos 1361-1363, nos quais Zeus é invocado novamente. Observa-se, aqui, a ironia de tal situação, pois Ártemis havia anunciado que não pudera salvar Hipólito, tendo em vista o temor que a deusa possuía de seu pai, Zeus: "Elevai-me como convém, arrastai-me atentamente, / o infortunado e infando / pelas faltas paternas. Zeus,

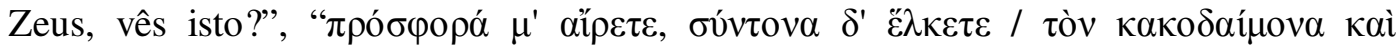

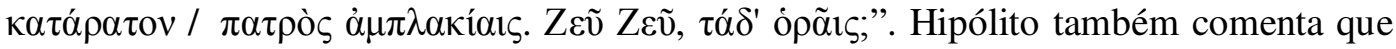
todos os seus sofrimentos têm origem em um antepassado, v. 1379-1383,

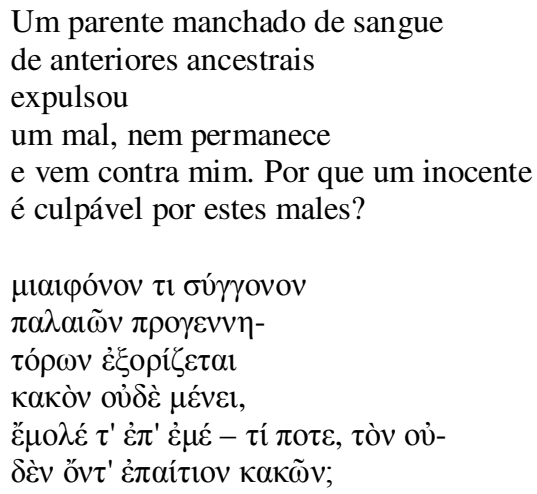

O filho da amazona não questiona a possibilidade de que tenha realizado algo de errado através de seus atos e de suas falas na sua relação com os indivíduos em sociedade. Não cogita os erros cometidos por si mesmo, porém atribui a responsabilidade pela sua desgraça a tudo e a todos- o jovem é, pois, mais imaturo que Fedra. Para Hipólito, todos erraram - até os cavalos são os responsáveis por sua desventura. Onde está aquele homem que ostentava poder no prólogo e também no segundo e terceiro episódios? O personagem demonstra o quanto está fechado em si mesmo, não está aberto às novas experiências e às críticas que lhe são advindas por falar ou por agir do modo que lhe convém. Observa-se, aqui, que recusar a paixão da sua madrasta é uma metáfora da não-participação do indivíduo no mundo. Depois que o personagem tripudiou a paixão da rainha, a morte torna-se um recurso para que Hipólito reconheça que parte da essência da vida significa a seriedade nas relações humanas e não como até esse momento realizou no seu convívio com os outros indivíduos.

Ao se refletir mais de perto a respeito da relação entre um mortal e uma imortal, há a seguinte questão a ser esclarecida: se Hipólito não enxerga Ártemis, como se dá o contato entre ambos ainda que não seja por meio da linguagem oral? Isso ocorre através do perfume. O teórico Lattimore apresenta uma hipótese mais ousada: acredita que Hipólito ama Ártemis como se fosse uma mulher, visto que a voz, a fragrância (ỏo $\mu \tilde{\eta} \varsigma$, v. 1391) e a presença seriam tudo aquilo de que o jovem necessita e que espera da deusa (Lattimore, 1962, p. 16). Desta maneira, sentir o perfume de Ártemis produz o reconhecimento da presença da divindade. Em contraponto com essa perspectiva, encontra-se a palavra "ỏ $\sigma \mu \eta ́ v "$, em Antígona, de Sófocles, que sugere uma outra conotação - lá, trata-se do odor do cadáver de Polinices, versos 412 e 1083. Já no texto de Eurípides, a deusa olha o rosto destruído do herói e sente o cheiro de seu sangue -

Organon, Porto Alegre, nº 49, julho-dezembro, 2010, p.239 - 256 
esse é o limite entre os mortais e imortais. Além disso, essa divindade encobre ainda mais a percepção dos erros do filho de Teseu, pois elogia o comportamento do

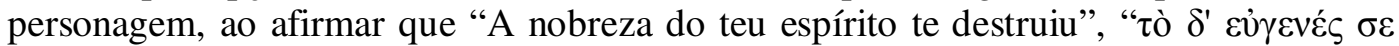
$\tau \tilde{\omega} v \varphi \rho \varepsilon v \tilde{\nu} v \dot{\alpha} \pi \omega ́ \lambda \varepsilon \sigma \varepsilon v "$, v. 1390.

No diálogo a seguir, a deusa e o jovem concordam que o responsável pela desgraça foi Cípris: Ártemis: "A malvada Cípris tramou isto"; Hipólito: "Ai, entendo que um Nume me destruiu"; Ártemis: "Acusava-te por não a honrares, irritava a tua

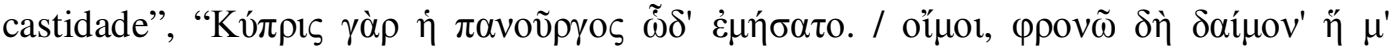

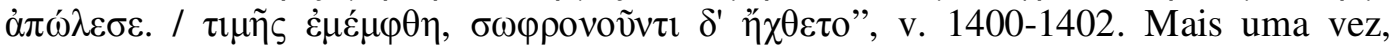
repete-se a idéia da impossibilidade de reflexão sobre os atos de Hipólito que o colocaram nesse tipo de situação. Além disso, não se trata de uma simples vingança dentro da lógica este por aquele, Hipólito por Adônis - o texto nem informa o nome do ente favorito de Afrodite. Trata-se, pois, de um recurso que Eurípides empregou para enfatizar a escolha de Ártemis e não a vítima (Adônis) que morrerá posteriormente. Hipólito, anteriormente, revelou que odiava e que não tolerava a existência das mulheres. Se Afrodite tramou a morte de Hipólito - que é amado por Ártemis —, essa segunda deusa também matará um mortal com quem possuía relações amorosas, isto é, Adônis.

O que resta para Hipólito após a paixão de Fedra ter-lhe retirado a vida e ter lançado a sua imagem como homem, como um ser predileto de uma divindade, em dúvida? Ártemis concede a Hipólito uma cerimônia em sua homenagem; no entanto, esse evento suscita mais questionamentos sobre as atitudes deste último, conforme os versos 1423-1430,

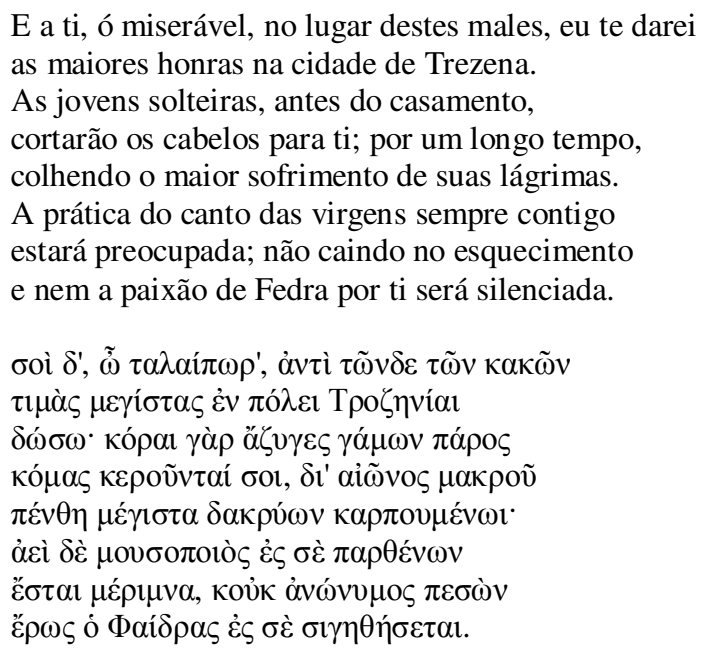

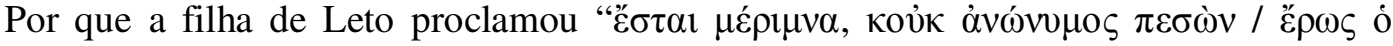

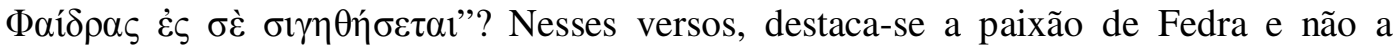
injustiça praticada contra Hipólito? Parece que a injustiçada foi efetivamente Fedra e não Hipólito - é o que pode se inferir a partir do texto. A rainha sofreu, pois não foi satisfeita em sua paixão, e necessitou permanecer em silêncio. É importante, neste momento, recordar que Ártemis não está somente envolvida com os animais da floresta, com os bosques e com a virgindade: alguns assuntos, como o nascimento das crianças, pertencem à esfera dessa divindade, conforme o relato do coro no párodo, v. 165 ss. 
Embora Ártemis tripudie Fedra, há o indicativo de que Hipólito não seria aquele que permaneceu na pior situação, mesmo que tenha sido morto por uma acusação falsa.

É importante, agora, registrar que a combinação entre a desgraça e a nobreza da rainha permite estabelecer vínculos com Hipólito. Esse personagem padece da feminilização, devido à sua passividade nos eventos que lhe garantem a honra e também graças ao espaço restrito, isto é, o prado onde revela a sua nobreza. Mencionado no prólogo, na verdade, tal espaço geralmente na Literatura Grega está associado a desejos eróticos e a assuntos mitológicos - por isso, é estranho que um jovem nesse local entre e proclame que é casto (Bremer, 1975, p. 275 ss). Como poderia Fedra ter relação com o jovem, se ele assume atributos femininos?

De acordo com Barbara Goff, elementos como a coroa, o prado e a partida de Hipólito do palácio (este personagem, após a tentativa de aproximação com a rainha, feita pela nutriz, decidiu afastar-se do referido lugar) indicam que ele acolheu, de forma violenta, a feminilização. A helenista observa que, na carta de Fedra (que ela escreveu antes de morrer) e no discurso de Teseu, Hipólito é reduzido à posição de uma mulher que permanece em silêncio ou, quando usa da fala, não alcança o efeito de persuadir as pessoas (Goff, 1996, p. 65). A autora também comenta que o discurso do filho diante do pai convém à feminilização, pois Hipólito, ao proclamar "pois tenho a alma virgem", “ $\pi \alpha \rho \theta \dot{v} v o v \psi v \chi \eta े v ~ \varepsilon ̌ \chi \omega v ", ~ v . ~ 1006$, emprega uma expressão que normalmente designa as mulheres. Além disso, utiliza termos como aoikos (sem casa) e apolis (sem cidade) que seguidamente estão relacionados ao comportamento das mulheres nas peças de Eurípides (Goff, 1996, loc. cit.).

Há outros personagens desse tragediógrafo que adotam, por algum momento, um comportamento semelhante, como Admeto, em Alceste (438 a. C.), que é deixado pela mulher. O personagem realiza uma paternidade com traços de mãe, isto é, depois da morte da esposa, ele cuidará dos filhos do casal. Admeto é condenado a viver como uma virgem ou como uma esposa casta dentro do palácio. Alceste partiu de sua casa, a fim de que pudesse morrer no lugar do marido - é ela quem obtém o espaço para as explorações viris (Loraux, 1985, p. 58). Esse quadro se aproxima do futuro de Teseu que permanecerá em seu palácio vivendo e cuidando dos seus filhos que teve com Fedra.

É curioso observar que a instituição do casamento foi rejeitada por Hipólito, conforme os versos 14 e 616 ss. Em contrapartida, com a interferência de Ártemis, que estabelece um ritual em Trezena, o referido personagem terá o seu nome perpetuado nas cerimônias de casamento realizadas na cidade, v. 1423-1430 (Segal, 1988, p. 55). Nos casamentos, eram realizadas algumas lamentações funerárias; na peça, por exemplo, tem-se o ato das mulheres de Trezena que cortam o cabelo e que se lamentam por Hipólito, v. 1425-1429 (Seaford, 1987, p. 113). Neste sentido, trata-se, pois, de um topos o lamento de uma moça a respeito de um jovem, quando esse não é casado, como é o caso do filho da amazona, ao ter sido exilado e que, quando retorna à sua terra, é para a sua morte (Hallerran, 1991, p. 120). Michael R. Halleran ainda comenta que a vingança de Ártemis contra Adônis, o favorito de Afrodite, não é efetivada por causa de uma transgressão sexual, isto é, não é pela conduta sexual de Adônis que este último morrerá, mas sim isso funciona como um ato de retaliação a Afrodite.

Apesar das particularidades religiosas que são demarcadas por Ártemis, novamente se poderia assinalar a estranheza da participação das mulheres no ritual, ao prestarem uma homenagem àquele que as menospreza ferozmente. Neste sentido, Hipólito seria relembrado em uma cerimônia na qual está em jogo não somente a crítica 
contra as mulheres e a sua pureza sexual mas também englobaria uma instituição na qual até esse momento aquele se mantinha distante: o casamento. Há um indicativo de que a presença desse ritual constitui em uma crítica indireta da divindade em relação a Hipólito.

Outro tema que agora merece ser comentado é que a possibilidade da reconciliação entre os membros da família é freqüente no final das obras de Eurípides. Em Hipólito, destaca-se a philia que surge entre pai e filho que não existia anteriormente na peça — é graças à paixão que há um aflorar daquele sentimento. Observa-se uma outra caracterização do tema da philia quando se avaliam as peças de Eurípides, se se compara, por exemplo, o relacionamento entre Hipólito e Teseu em contraponto com Admeto e Feres da tragédia Alceste. Nos versos 614 ss, Admeto solicita ao pai, ancião, que troque a sua vida por sua nora Alceste, que em breve morrerá por ter trocado o seu lugar com o marido - o velho não aceita a proposta. Na seqüência, há inúmeros insultos e nenhum dos dois cede: Admeto acusa o pai e Feres ao filho. Registra-se uma longa cena na qual prevalece o egoísmo de ambos os personagens e o resultado disso é que Admeto permitirá que a sua esposa vá no seu lugar — deste modo, ele não aceita o desafio da morte. A situação entre Hipólito e Teseu é distinta, pelo fato de que, pelo menos, o filho acatou as decisões do seu pai no terceiro episódio: o jovem afirma, v. 1090-1091, "A sentença está dada, como parece. Ó sou miserável, /

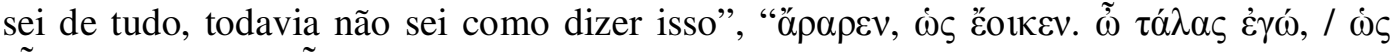

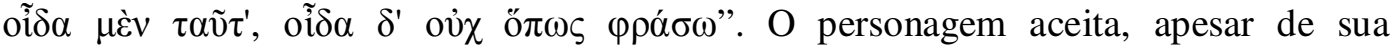
contrariedade, as ordens do pai, ainda que o primeiro esteja convicto de que é inocente. De fato, o filho da amazona não é um ser perverso: pode sim ser caracterizado como arrogante, como misógino. Possui as suas opiniões sobre o mundo e mantém, segundo as suas declarações na tragédia, uma intensa relação com o divino; no entanto, comete equívocos em relação a Cípris e quanto a algumas exigências sociais e psíquicas as quais não cede, julgando plenamente estar praticando o que é correto, o que deve ser feito.

Ainda, pode-se estabelecer uma relação entre Héracles e Anfítrion (da tragédia Héracles), cuja morte ocorreria, se não fosse a intervenção de Palas Atena ao arremessar uma pedra no herói. É interessante o relato de Pausânias que julgava ter visto, em Tebas, no santuário de Héracles, a pedra que fora lançada por Palas Atena contra esse herói quando estivera possuído pela loucura, ameaçando matar filhos e Anfítrion, conforme Pausânias, IX, 11, 2. O nome dessa pedra é sophronister (Vernant, 1986, p. 62). Aqui, o pai exerce o papel de indivíduo revelador dos males que o filho havia provocado contra a sua família. Anfítrion possui justamente a ponderação para avaliar a situação, e o seu filho, Héracles, diante dos assassinatos que cometeu contra os seus entes queridos, nem mais deseja continuar a viver. Além disso, há um agravante, pois Anfítrion foi testemunha dos atos insanos do seu filho. O pai contemplou a insanidade, porém nem por isso deseja a morte de Héracles. Teseu podia ter seguido um caminho semelhante, contudo preferiu guiar-se pelos seus próprios juízos, deixando de lado as sugestões de Hipólito e as admoestações do coro. Retomando o que se disse, Anfítrion soube diferenciar as ações que pertencem à índole de seu filho e as ações que foram atribuídas à sua repentina loucura, visto que o pai desconhece que os deuses foram os causadores dos males de Héracles. Teseu, como foi comentado anteriormente, permanece satisfeito com o cadáver de Fedra e com a tabuleta (a carta) e, em nenhum momento, questiona os elementos de acusação, nem se tudo tivesse sido obra de um plano arquitetado por uma divindade. Em termos de contraponto, Anfítrion presenciou o 
ato de seu filho e o seu respectivo resultado, ao passo que Teseu, somente este último aspecto. $\mathrm{O}$ pai de Héracles poderia ter sido induzido a realizar um julgamento terrível tanto quanto Teseu realizou com o seu filho - no entanto, não foi isso o que ocorreu.

D. J. Schenker observa que os deuses não são contrários à possibilidade de que ocorra a reconciliação entre os personagens (Schencker, 1995, p. 9). O autor cita outros teóricos como George Devereux e Barbara Goff que consideram que a cena final é realizada graças à concessão da parte divina. Hipólito não reconhece a dor do seu pai até que Ártemis lhe aponte isso no verso 1404. De acordo com Schenker, Hipólito não coloca o pai como um dos três seres que estão infelizes com a iminência da sua morte. Neste sentido, a função do humano em relação ao divino na reconciliação entre pai e filho diminui, pois é Ártemis quem assinala, em um primeiro momento, que o jovem deva acolher o seu pai. O helenista também afirma que essa situação indica a pureza que ainda pode estar presente no ser humano, apesar de tudo que ocorreu entre os personagens.

De fato, o êxodo traz o que é ressaltado desde o início da tragédia: a paixão amorosa da rainha pelo enteado contribuiu para dizimar uma estrutura familiar. Tal sentimento fornece índices de que questões, como, por exemplo, o feminino, o papel da mulher na sociedade, a força dos sentimentos, a falta de uma proximidade do pai com a sua família necessitavam ser reavaliadas no mundo grego. Se a paixão é algo natural, mesmo que o objeto desejado seja proibido (a madrasta que deseja o jovem enteado), a sua presença, aqui, é significativa para revelar como a sociedade está administrando os seus problemas e os seus conflitos. O êxodo retomou alguns desses aspectos, não deixando de acentuar ainda a tensão dramática. Assim, Teseu terá que permanecer no seu palácio, sozinho, com os filhos que teve com Fedra. Seria, pois, a oportunidade para interrogar a si mesmo (se é que o personagem conseguirá fazer isso ou se partirá para uma nova viagem para suportar a sua desdita) a respeito dos seus erros, relembrando do seu amado filho e igualmente de sua esposa.

\section{BIBLIOGRAFIA}

BARRETT, W. S. Hippolytos. Intr. e coment. de W. S. Barrett. Oxford: Claredon, 1964. BREMER, J. M. The meadow of love and two passages in Euripides'Hippolytus. Mnemosyne, Países Baixos, v. 28, fasc. 3, p. 268-280, 1975.

CROCKER, Lester G. On interpreting Hippolytus. Philologus, Berlin, v. 101, p. 238246, 1957.

EISNER, Robert. Euripides' Use of Myth. Arethusa, v. 12, p. 153-174, 1979.

EURÍPIDES. Children of Heracles. Hippolytus. Andromache. Hecuba. Trad. David Kovacs. London: Harvard University Press, 1995. v. 2.

FÉREZ, Juan Antonio López. Retórica y tragedia em Eurípides. Atas do III Simpósio Internacional Investigações Semióticas III, Madrid, p. 57-71, 1988.

GOFF, E. Barbara. The noose of words: readings of desire, violence \& language in Euripides' Hippolytos. Cambridge: Cambridge University Press, 1996.

HALLERAN, Michael R. Gamos and Destruction in Euripides' Hippolytus. Transactions of the American Philological Association, v. 121, p. 109-121, 1991.

LATTIMORE, R. Phaedra and Hippolytus. Arion, Brookline, v. 1, p. 5-18, 1962.

LORAUX, Nicole. Façons tragiques de tuer une femme. Paris: Hachette, 1985. (Textes du $X^{\mathrm{e}}$ Siecle).

Organon, Porto Alegre, nº 49, julho-dezembro, 2010, p.239 - 256 
LUSCHNIG, C. A. E. The value of ignorance in the Hippolytus. American Journal of Philology, Baltimore, v. 104, n. 2, p. 115-123, 1983.

RIVIER, André. Essai sur le tragique d'Euripide. 2. ed. Paris: Diffusion de Boccard, 1975.

SCHENKER, D. J. The victims of Aprodite: Hippolytus, 1403-05. Mnemosyne: a Journal of Classical Studies, Países Baixos, v. 98, fasc. 1, p. 1-10, fev. 1995.

SEAFORD, R. A. S. The tragic wedding. Journal of Hellenic Studies, v. 107, p. 106130, 1987.

SEGAL, Charles P. The tragedy of the Hippolytus: the waters of ocean and the untouched. Harvard Studies in Classical Philology, v. 70, p. 117-169, 1965.

_. Curse and oath in Euripides' Hippolytus. Ramus, v. 1, p. 165-180, 1972.

. Theatre, ritual and commemoration in Euripides'Hippolytus. Ramus, v. 17, p. 5274, 1988.

VERNANT, Jean Pierre. As origens do pensamento grego. 5. ed. Trad. Ísis Borges B. da Fonseca. São Paulo: Difel, 1986. 